\title{
Переговорный процесс как важнейший способ разрешения Афганского конфликта
}

Мангал Бисмиллах

В настоящее время в Афганистане не существует никаких других способов разрешения возникающих в нашем обществе конфликтов, кроме организации посредничества и переговоров. В ст. 33 Устава ООН непосредственные переговоры стоят на первом месте. Согласно Уставу ООН мирными средствами урегулирования международных споров ООН являются переговоры, обследования, посредничество, примирение, арбитраж, судебное разбирательство, обращение к региональным органам или соглашениям. Устав ООН предоставляет сторонам - участницам спора право выбора любого мирного способа разрешения спора. Мирные средства урегулирования международных споров, указанные в ст. 33 Устава ООН, не являются исчерпывающими.

Переговоры - одно из самих гибких средств урегулирования разногласий. Они могут проводиться как на официальном уровне, вплоть до Глав государств, так и неофициальном - письменно, устно, «без галстуков». Дополнительным преимуществом непосредственных переговоров является факт невозможности какого-либо давления со стороны третьих государств, международных организаций.

Ключевые слова: Афганистан; переговоры; посредничество; урегулирование международных споров.

Очевидно, что в настоящее время в Афганистане не существует никаких других способов разрешения возникающих в нашем обществе конфликтов, кроме организации посредничества и переговоров.

В ст.33 Устава Организации Объединенных Наций (далее - Устав $\mathrm{OOH)} \mathrm{непосредственные} \mathrm{переговоры} \mathrm{стоят} \mathrm{на} \mathrm{первом} \mathrm{месте.} \mathrm{Соглас-}$ но Уставу ООН мирными средствами урегулирования международных споров ООН являются «переговоры, обследования, посредничество, примирение, арбитраж, судебное разбирательство, обращение к региональным органам или соглашениям $\rangle^{1}$. Устав $\mathrm{OOH}$ предоставляет сторонам - участницам спора право выбора любого другого мирного способа разрешения спора ${ }^{2}$. Однако мирные средства урегулирования

\footnotetext{
* Мангал Бисмиллах - соискатель кафедры международного права МГИМО (У) МИД России. mangalafg@yahoo.com.
} 
международных споров, указанные в ст. 33 Устава ООН, не являются исчерпывающими.

Переговорный процесс признан во многих международно-правовых актах, например, в Гаагских конвенциях 1899 и 1907 годов, Декларации о принципах международного права ООН 1970 г., Заключительном акте Совещания по безопасности и сотрудничеству в Европе 1975 г.

Переговоры являются главным средством решения международных, а также внутригосударственных споров. Фактически, все средства мирного урегулирования имеют непосредственную связь с переговорами: двусторонние и многосторонние переговоры применяются на международных конференциях, при участии третей стороны (добрые услуги, посредничество). Использование консультационных органов (согласительных и следственных комиссий), судебных разбирательств (Международный и третейский суд) также невозможны без непосредственных переговоров.

Переговоры - одно из самих гибких средств урегулирования разногласий. Они могут проводиться как на официальном уровне, вплоть до Глав государств, так и неофициальном - письменно, устно, «без галстуков». Дополнительным преимуществом непосредственных переговоров является факт невозможности давления со стороны третьих государств, международных организаций.

Любое политическое решение (согласие), принятое с помощью переговоров, является желательным результатом разрешения конфликта в Афганистане. Однако в настоящее время переговоры с талибами не всегда могут привести к устойчивому миру. Существует риск, что переговоры в нынешних условиях иногда дестабилизируют обстановку в стране и регионе. Ослабленное внутренними политическими разногласиями и внешним давлением, правительство Афганистана находится в невыгодном положении, для того чтобы заключить сделку с лидерами повстанцев.

Силы безопасности Афганистана не готовы справиться с вакуумом власти после вывода международных войск. Политическая конкуренция нагревается внутри страны в преддверии вывода войск НАТО (Организация Североатлантического договора) ${ }^{3}$ в конце 2014 года. Разные приоритеты и предпочтения сторон в конфликте - от афганского правительства к руководству талибов и ключевых региональных и более широких международных организаций - могут еще больше подорвать перспективы мира. Во избежание новой гражданской войны, 
необходимо, чтобы $\mathrm{OOH}^{4}$ приняла основные коррекции курса, которые приведут к назначению посреднической группы и принятию более реалистичного подхода к урегулированию конфликта.

Когда США и их союзники по НАТО хотят уйти из Афганистана, жизненно важным является то, что соглашения, которые будут достигнуты с помощью переговоров, способствовали бы сохранению достижений последнего десятилетия. Для достижения прочного мирного соглашения, в конечном итоге, требуются в рамках ООН гораздо более структурированные переговоры, по сравнению с тем, что делается в настоящее время. Совету Безопасности ООН необходимо поручить Генеральному секретарю ООН Пан Ги Муну как можно скорее назначить небольшую группу для обеих сторон взаимоприемлемых посредников; нужна гарантия заинтересованных сторон, которые бы в полной мере участвовали в переговорном процессе.

До сих пор отсутствуют признаки признания любой из сторон в конфликте остроты ситуации. Вместо того чтобы последовательно проводить дорожную карту, приоритетом которой является внутреннее примирение, которое включает в себя основные политические силы, сопровождающиеся многосторонними усилиями медитации, афганское правительство и его международные покровители взяли на вооружение рыночный подход к переговорным процессам, цель которых является ведением переговоров с любыми и всеми желающими, независимо от их политической актуальности или способности влиять на результаты. Международные сообщества в переговорных процессах до сих пор поддерживали и стимулировали повстанцев, которые состоят из нечестных правительственных чиновников и военных спекулянтов, у которых есть сомнительная репутация и из войны получают выгоду. Вышеуказанные лица хорошо знают, какие соглашения необходимы, а какие нет. Кроме того, стало ясно, что целью международного сообщества является скорейший вывод войск из Афганистана.

Усилия правительства начать переговорный процесс были малозначительными и бессистемными. Среди фундаментальных разногласий по самому смыслу примирения процесс сосредоточен на политическом компромиссе с группами с сомнительной репутацией. Риторический шум о переговорах привел к отчаянным и опасным движениям, и правительство не смогло довести единого предложения лидерам трех основных повстанческих групп - Талибан, Хизб-и-Ислами и сети Хаккани - сесть за стол переговоров. Данный подход разжигает страхи 
среди этнических меньшинств, в гражданском обществе и среди женщин, в результате чего образуется вакуум среди населения. По некоторым данным целью политики примирения Президента Х. Карзая является укрепление своего избирательного округа среди консервативной элиты пуштунских племен. Такой подход противоречит интересам других граждан. В связи с изложенным, необходимо пересмотреть политику национального примирения и роль Высшего совета мира и процесс реинтеграции в Афганистане.

Таким образом, Программа политико-национального примирения столкнулась со стойким сопротивлением со стороны местных силовиков и недоверием заинтересованных участников.

Афганское правительство должно включать в мирные переговорные процессы всех соответствующих внутренних игроков, а не текущей амальгамы полевых командиров. Для формирования повестки дня переговорного процесса необходимо создать небольшую группу, имеющую опыт работы в национальных и международных делах. Переговорная группа правительства должна отражать разнообразие страны - языковое, этническое, религиозное. В нее также должны входить представители Афганской независимой комиссии по правам человека (АНКПЧ) и Совет национальной безопасности (СНБ). Включение представителей политической оппозиции - консерваторов и прогрессистов - будет иметь решающее значение для успеха. Правительство должно гарантировать, что достигнутые соглашения защищают права всех граждан. Прозрачность в проведении переговоров и более тесных связей с общественностью и политической оппозицией, этническими меньшинствами, женщинами и широким кругом субъектов гражданского общества будет иметь решающее значение для переговорного процесса.

Меры укрепления доверия не должны быть ограничены. Необходимо завоевать поддержку не только Талибан, но и сосредоточиться на привлечении к переговорному процессу широкого круга людей для урегулирования конфликта. Любая сделка, которая дает льготу Талибан, приведет к значительной негативной реакции со стороны Северного альянса, Хизб-и-Ислами и других крупных фракций. Заключение любой тайной сделки с талибами может привести к дезертирству в государственных учреждениях, в частности, среди органов сил безопасности, и поэтому, по мнению некоторых зарубежных и афганских 
ученых, на Контингенты МССБ лежит большая ответственность по урегулированию внутри афганского конфликта.

\section{The Negotiation Process as one of Essential Means of Resolving the Afghan Conflict (Summary)}

\section{Mangal Bismillah*}

The article is devoted to the negotiation process in Afghanistan as the most important way to resolve the Afghan conflict. The negotiation process is one of the essential means of resolving the Afghan conflict. It is clear that in the current situation in Afghanistan, there are no other ways to address emerging conflicts in our society, but the organization of mediation and negotiation.

In Article 33 of the UN Charter direct talks are the first priority, according to which the peaceful means of settling international disputes are the UN negotiation, inquiry, mediation, conciliation, arbitration, judicial settlement, resort to regional agencies or arrangements. The Charter also reserves the participating parties to the dispute may choose any other peaceful means of resolving the dispute. Peaceful means of settling international disputes referred to in Article 33 of the Constitution are not exhaustive.

The talks are one from the very flexible means of resolving differences. They can be carried out both at the official level, up to the heads of state and informally - in writing, verbally, "without ties". Another advantage of direct talks is that hindered any pressure from third countries, international organizations.

Keywords: Afghanistan; negotiations; mediation; settling of international disputes.

\footnotetext{
* Mangal Bismillah - post-graduate student of the Chair of International law, MGIMOUniversity MFA Russia. mangalafg@yahoo.com.
} 
${ }^{1}$ Международное право: учебник / под ред. А.Н. Вылегжанина. - М.: Изд-во Юрайт, ИД Юрайт, 2011. - 1003 с.

${ }^{2}$ Статья 33 Устава ООН.

${ }^{3}$ URL: http://www.nato.int.

${ }^{4}$ URL: http://www.un.org. 